\title{
This god is your god, this god is my god: local identities at sacralized places in Roman Syria
}

\begin{abstract}
Numerous sacralized places with a wide range of architectonic, iconographical, and epigraphical-linguistic motifs, habits, and religious practices populate the Roman provinces of Syria and Syria Phoenice (Mount Hermon, plain of Beqaa, Lebanon mountains). This paper examines the socio-spatial strategies used at some of these sacralized places between the 1st and 3rd centuries CE in order to establish a local identity by making use of local deities. By applying a spatial approach and explaining sacralized places as spaces of lived religion, the local character of common deities, such as Dea Syria, Zeus, or Leukothea, come to the fore, whereas others (Hadaranes, Mifsenus) are seen to be inherently local, since they are unique to the place. Communication and negotiation through local divine agents of the interests, needs, status, and connections of local residents seems to have provided a vital means for clarifying the belonging of individuals to specific places in a world of changing territorial boundaries. Spatializing religion in this way is an approach to the archaeology of religion that takes proper account of the importance of places, contexts, and objects.
\end{abstract}

\section{Point of departure: local deities and place-bound identities in Roman Syria}

Numerous sanctuaries and temples populated the landscapes of Roman Syria and Syria Phoenice, providing venues for the local population and visitors to venerate and communicate with a huge variety of deities (Kaizer 2008). Many

\footnotetext{
Acknowledgement: I would like to express my sincerest gratitude to Jörg Rüpke, the director of the ERC Advanced Grant No. 295000 “Lived Ancient Religion”, and to co-director Rubina Raja, for enabling us to study ancient Mediterranean religion in such a fruitful way. The audiences at the conference and at the Max-Weber-Kolleg offered very helpful comments on earlier drafts of this paper, especially Barbara E. Borg, David Frankfurter, Valentino Gasparini, Harry O. Maier, Georgia Petridou, Jörg Rüpke, Bjørn Schiermer Andersen, Emiliano Urciuoli, and Jutta Vinzent. I would also like to thank Paul Scade for his diligent and committed copy-editing.
} 
of the gods and goddesses were either addressed by unique names or were associated with the area by the addition of localizing epithets. Taking these local and/or localized deities as a point of departure, my discussion will focus on the distinctions between the sacralized places, ${ }^{1}$ their divine owners, and the human counterparts of these divinities. Drawing on case studies from the Hermon ranges and the Beqaa plain, I aim to show that the sheer number of such places within a small area played an important role in the negotiation of identities throughout the region and helped to determine where people belonged, economically, individually, and imaginatively. A fundamental aspect of the identity of human agents is their local, spatially defined identity. ${ }^{2}$ I claim here that the local specification of deities and the identity-shaping of their human counterparts occurred at the sacralized places due to tensions between local interests and those of outsiders, primarily concerning agricultural resources and especially in the 1st to 3rd centuries CE.

I follow Massey $(2005,154)$ in defining local identity by reference to places that "are formed through a myriad of practices of quotidian negotiation and contestation; practices ... through which the constituent 'identities' are also themselves continually moulded. Place ... does ... change us ... through the practising of place." In addition to her practice-oriented conceptualization of places, Massey also draws attention to the non-human dimensions of place (2005, 140): "Place ... is not some romance of a pre-given collective identity or of the eternity of the hills. Rather, what is special about place is precisely that throwntogetherness, the unavoidable challenge of negotiating a here-and-now (itself drawing on a history and a geography of thens and theres); and a negotiation which must take place within and between both human and nonhuman." Hence, sacralized places can be understood as the crystallization of the negotiation that human beings embark on with the support of divine agents as they aim to carve out their position within their social and natural environments.

It is particularly challenging to approach the question of identity in the highly diverse, multi-lingual, -scriptural, and -cultural region of Roman Syria. Religious phenomena are often analyzed to provide criteria for differentiating and, thus, creating the - conjecturally collective - identities of groups and communities living in this region (Teixidor 1977; Sartre 2001, 926; Aliquot 2009,

1 I prefer to use the term "sacralized places" for sanctuaries, sacred places, and the like, since this term better conveys that the sacred character of places is not a given fact but is, rather, negotiated in a continuous process of sacralization in varying intensities, Albrecht et al. 2018, 582.

2 Only secondarily Roman, Syrian, Hellenized, or native identities may be at stake - all themselves constructed. 
155-194; Butcher 2011; Hošek 2012; Andrande 2013). Recently, Ted Kaizer (2013; 2015) has acknowledged clearly the importance of the "locale" of religious expressions in the Near East, at the same time locating them within the wider frame of the Mediterranean world (local vs. global). ${ }^{3}$

I aim to complement Kaizer's approach by focusing on one individual place, to which I will apply a spatial methodology that parallels lived religion with lived space. In doing so, I will inquire into the identity formation of individuals through their communication with deities and co-users at sacralized places in Roman Syria. It is through and in these landscapes and places, I argue, that place-bound identity is constructed and negotiated. ${ }^{4}$ A spatial approach helps us to understand these places as locations in which a local identity, which forms part of nested individual or group identities, is founded. With the focus on identity and space, the religious practices taking place in these locations establish, confirm, or distinguish the negotiated identities and clarify the relations that hold with other groups or places, both within the community and beyond.

\section{Areas of action: lived space and lived religion in Roman Syria}

If we take as our starting points the phenomenological assumptions that (a) we live space, rather than live in space, and (b) that space is produced by practices, then space takes on an agentic role, acting alongside people, time, and objects. Since religious practices are also spatial practices, we can examine religious places in Roman Syria as produced and negotiated spaces (cf. Brace et al. 2006; Knott 2005, esp. 122-123), and ask a number of important questions. How did people relate to the various deities within their locale? What were the interrelations, connections, and distinctions between divinities, sacralized places, and users in the villages of Mount Hermon, Mount Lebanon, or the Beqaa plain, such as Niha, Bethmare, or Seigeira? How did spaces participate in constructing,

3 For a summary of the history of religious studies on the Greco-Roman Near East, see Kaizer 2008; for differentiated approaches, see Belayche 2009 and Isaac 2009. My paper can be understood as an attempt to meet the claim by Kaizer 2008, 23 to approach the varieties of religious life via the toponymic deities.

4 Mediterranean Archaeology has dealt with the construction of ethnic or cultural and social identity (Hall 1998; Hodos 2010); see also Cifani and Stoddart 2012. MacSweeney 2011 includes local communities in concepts of identity. 
communicating, and negotiating identities in the region? What agency did sacralized places develop in addition to their religious function, and what are the capacities of such places for constructing relationships in the immediate local and regional settings?

\subsection{Towards a spatial methodology for ancient religion}

Spaces, as well as the spatial relations associated with the multifarious identities of individuals and groups, are parts of the agentive network involved in doing religion (cf. Gasparini this volume; Hunter-Crawley this volume). If we live space, and space is thus reciprocally produced by human actions just as human actions are produced by space, the consequences for our understanding of religious spaces are highly significant. Rather than thinking that we carry out rituals at a religious place, we must conclude that the spatial setting together with people, practices, dedications, sacrifices, and prayers interact to produce the religious place in on-going processes of sacralization. This process then also reciprocally shapes the settings, activities, and participants. Applying the paradigm of "religion in the making" (Albrecht et al. 2018), I attempt to move sacralized places out of the position of isolation and fixedness they have been placed in by the history of research on this subject. I acknowledge them as relational spaces (Massey 2004, 5-6, 10) formed by the deities and users, which experience significant physical changes that depend on developments in other spaces, communities, and societal groups.

An acknowledgment of the relation between identity, religion, and space can be brought to bear on the interpretation of sacralized places in Roman Syria in two ways: space and scales can be addressed as quantitative categories and can also be operationalized as qualitative dimensions for understanding social and socio-religious relations. "Space" embraces places (houses, villages, necropoleis, sacralized places) and landscapes (agricultural and "unprocessed" areas), all culturally constructed and imbued with meaning and memory (Ashmore 2004) through divine agents, the dead, daily necessities, and resources. Space just is lived space.

\subsection{Religious spaces as lived spaces}

I use the phrase "lived space" to refer to what Henri Lefebvre calls espace vécu, one of the intertwined dimensions of space he distinguishes in Le production de l'espace (1974). Even though religion does not feature in Lefebvre's discussion, 
he identifies three contemporaneously present and overlapping conceptual productions of space that can be used for approaching religious places (Lefebvre 1974, 48-49). The espace perçu, the repeated practices that take place in space, is materially and functionally perceivable and socially determined, as with "house", "field", and "street"; when applied to ancient religious spaces, we can identify parallel material categories such as "altar" or "temple". The espace conçu is the space that comprises aspects of power and socio-spatial order. It is space formed by institutions and specialists. Applied to ancient religious spaces, the conceived space correlates to the architectural concepts and traditions, the organization of ritual space according to an accepted set of religious knowledge. In my case, the espace perçu and conçu are defined by the broader cultural settings of the Eastern Mediterranean and Western Asian areas, taking in the political changes that started in the late 1st century BCE and the cultural, religious, and economic developments of the 2nd and 3rd centuries. The espace vécu corresponds to how agents describe or imagine their environment. The lived space embraces all strategies of appropriation, as well as counter-hegemonic activities. This is a subjective and mental dimension of space which includes stories and memories that relate past to present and future. Lived space is open for creativity and differentiation. In religious spaces, the aspect of lived space bears on selfworld-relations, on identity-building, and on imaginations.

By drawing a parallel between the notions of "lived space" and "lived religion” (Orsi 1997, 9-12, 17-18; Rüpke 2011; Albrecht et al. 2018) ${ }^{5}$ - which examines the experiences of practitioners, as well as situations, locations, and appropriations of religion from a bottom-up perspective on (everyday) life - I open up the means by which religious places in Roman Syria can be analyzed to approaches that study spatial arrangements, interconnections, and the valuations ascribed to them by various people (espace perçu). The background, i.e. from where the users of spaces come and in what institutional and architectonical frame they practice religion, corresponds to Lefebvre's espace conçu. The lived space (espace vécu) emerges from how those who use it shape and mark religious space and from the traditions in which they anchor their (group) identity.

5 Cf. the discussion of Jörg Rüpke's monograph Pantheon (Munich, 2016, Engl. translation 2018) with Corinne Bonnet, Jan Bremmer, Judith Lieu, and Zsuszanna Varhelyi at the conference, published in Religion in the Roman Empire 4 (2018). 


\section{Lines of relations and the location of identities at sacralized places in Roman Syria}

What impact do these premises have on our understanding of the large number of sacralized places that were within a day's walk for the populations of Mount Lebanon, the Mount Hermon area, or the plain of Beqaa (Massyas) (Fig. 1)? How can we grasp the local significance of, and the individual ascription of meaning to, these places and their deities by the groups or communities, villages or cities, who made use of them?

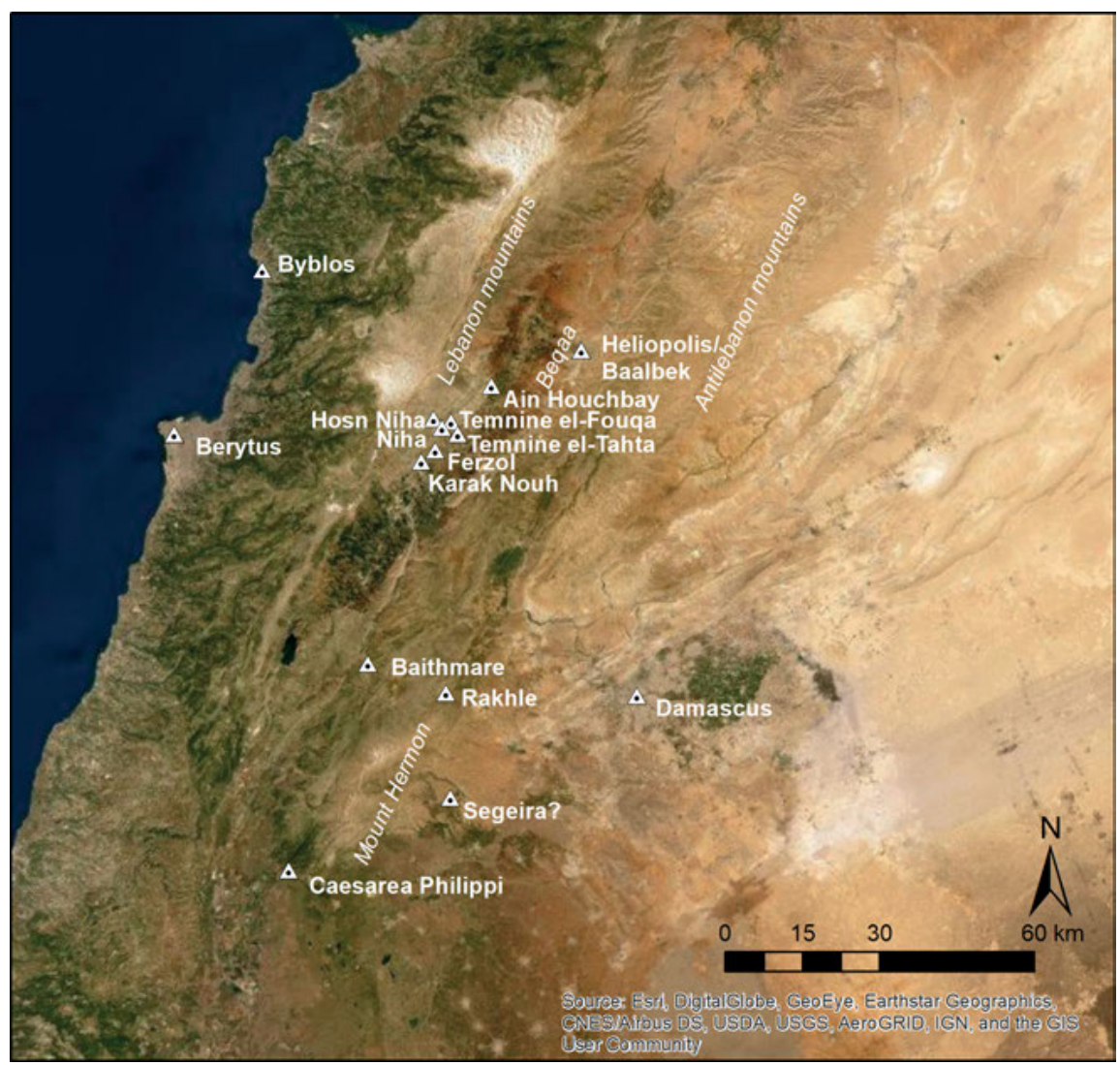

Fig. 1: Topographical view of the area of Mount Hermon, Lebanon, Anti-Lebanon and the Beqaa plain, and the places of Roman Syria mentioned in the text (see image for sources of satellite imagery, map created by the author with ArcMap). 
The places I consider in the southern area of Mount Hermon and the southwestern Beqaa provide examples of not only different designs, dimensions, fame, or deities, but also varying ecological and economic settings (Niha, Hosn Niha, Temnine el-Fouqa, Rakhle, Segeira, Baithmare; Fig. 1). I enquire into the shaping and communication of identities (cf. Borg this volume; Gasparini this volume) by revising and recontextualizing the material related to these sites (image-objects of deities and users, dedications, architecture), and by looking beyond the setting and architectural characteristics of a temple, its priests, statues, and inscriptions, or the worshippers who use it (Krumeich 1998; Freyberger 1999). This approach offers an insight into how local residents instrumentalized the tension between the local, the close-by, and the global (Massey 2004; Versluys 2015) in order to negotiate their needs, identities, and attitudes (Butcher 2011, 456) by acknowledging the spatial relations between places, objects, and religious groupings. We can ask a range of important questions. What kind of relationships did those who used a certain sacralized place have to the place itself and to other nearby places? What can we deduce about "belonging to the place" from the spatial layout, architecture, dedications, and, consequently, the religious practices associated with it? What kind of identityshaping can we deduce from these practices? How local was the construction of a social and spatial identity mediated through religious practices at the chosen places?

By considering particular sacralized places in terms of the differing scales within which they are embedded, from their immediate locale, through their surroundings and neighboring communities, and on up to the regional level, we can analyze their role in the place-attachment of residents. In doing so, we add to our understanding of the places as themselves agents in socio-religious processes.

The traditions of the Seleucid Empire, up to the 1st century BCE, and the political changes instigated by Rome's dominance of the region in the mid-2nd century CE (Millar 1993, 27-125, 225-385), are reflected in the accumulation of precincts, buildings, and altars to the gods in all regions of Roman Syria (and its subdivisions). Changes over time in political control of areas and networks of routes (Guillon 2013, up to the 1st century CE) influenced the political, administrative, and logistical conditions of the sacralized places and their users. ${ }^{6}$

6 The 1st to 3nd centuries CE in the Eastern Roman Empire stand for changes in the political administration, a general increase in interest in paideia (Borg 2004; Rutherford this volume); the interest in the body (Petridou this volume; Petridou 2016); and a new way of managing individual crisis (Belayche 2007). All these aspects are responsible for a competition among and an increasing interest in sacralized places all over the Mediterranean. 
At the same time, gods from the Western Asian provinces who were originally very local - Dea Syria, Zeus Heliopolitanus, Zeus Dolichenus - traveled with groups and individuals from their places of origin and spread as part of processes of appropriation, due to a combination of factors such as an interest across the Roman Empire in "exotic" deities, in religious Otherness, or in Antiquarianism (Belayche 2000; Blömer 2017; Versluys 2015). However, many other deities maintained their staunchly local guises, transmitting their vernacular character in names, epithets, and the places with which they were associated.

The dynamics of venerating these various local gods and goddesses, of setting up dedications, carving niches, or constructing buildings, depended not only on decisions, demands, and traditions at one specific site, but also on relationships that spanned other (sacralized) places, with their own practices, functions, and particularities. In order to acknowledge the multi-directional social and spatial positions of such places, the search for interdependencies needs to go beyond "central" places, such as provincial capitals and economic centers (Berytus, Byblos, Tyros) or large sanctuaries of supra-regional influence (Baalbek/Heliopolis), and look instead at the sacralized place "next door".7 Local places played a role in the daily, local, and generation-spanning organization of individual and family lives, and were involved in establishing and negotiating identities within a frame composed of general trends throughout the region. It is only on the next socio-spatial level that more distant cities - in their guise as economic, religious, and administrative centers - contribute to the picture of local identity formation through personal or virtual relations expressed in texts, images, offices, or practices such as tax payment.

\subsection{Jebel Sannine - bonds to deities valley for valley}

On the eastern slope of Jebel Sannine, we find at least six sacralized places located within an area of $10 \mathrm{~km}^{2}$ (Fig. 2). Niha and Hosn Niha are among the better-known temples of the Lebanon, due to the reliefs and inscriptions found there, as well as the character of the worshipped deities (Aliquot 2009, no. 59; Krencker and Zschietzschmann 1938, 105-121; Krumeich 1998; Newson and Young 2015). These two ancient settlements are located some $60 \mathrm{~km}$ east of Berytus. They are situated one above the other, roughly $2 \mathrm{~km}$ apart, on the slopes of Jebel Sannine, from where they look out across the river valley below.

7 This perspective also enables us to shed light on the interrelations of urban and rural spaces; for a good approach, see Schuler 2012. 


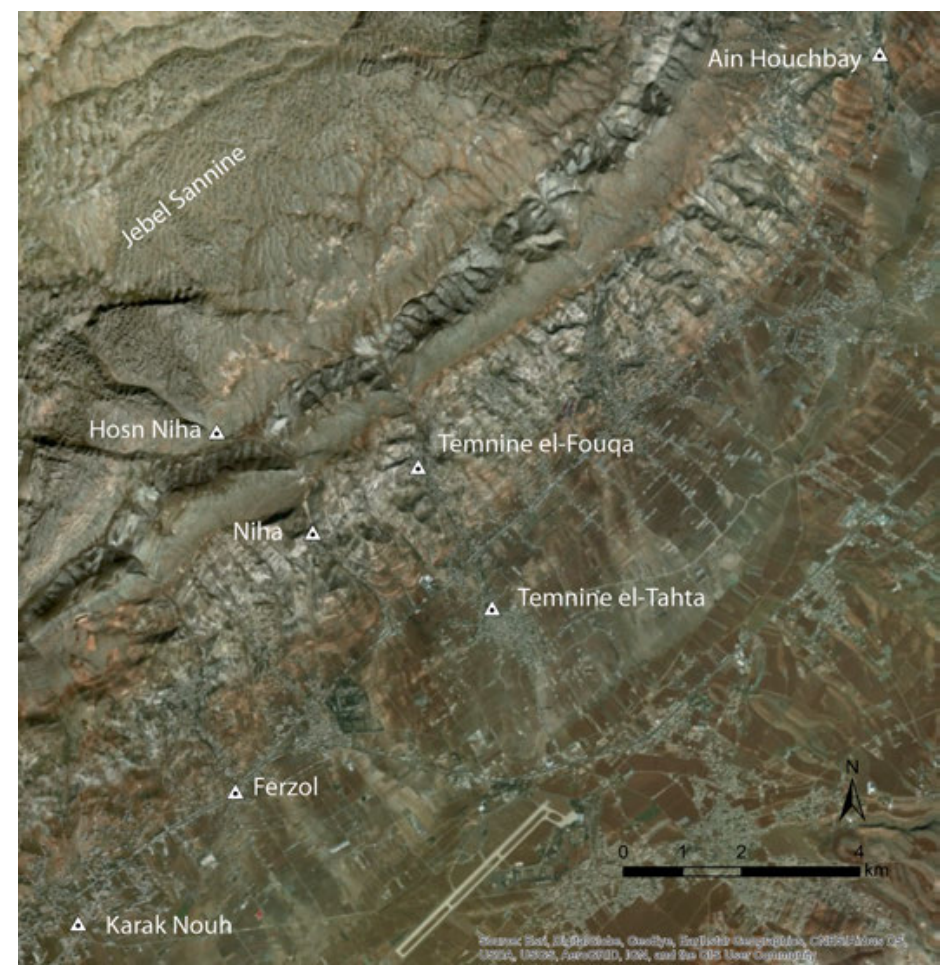

Fig. 2: Location of Niha, Hosn Niha and Temnine (see image for sources of satellite imagery, map created by the author with ArcMap).

Temnine el-Fouqa and Temnine el-Tahta are situated in the next valley, $1.5 \mathrm{~km}$ and $3 \mathrm{~km}$ to the northeast from Niha. The remains of necropoleis have been found in the area between Niha and Temnine el-Fouqa (IGLS 6, 2940-2945), and also at Ferzol and Karak Nouh, 3.5 and $4 \mathrm{~km}$ away to the south.

\subsubsection{Niha: local divine and religious celebrities}

The sanctuary at Niha with its buildings, inscriptions, and image-objects often serves as an example of how we can distinguish the various identities and ascriptions (especially "Romanness") of people living in ancient Lebanon, both the Hellenized Near Eastern populations and the "natives" (Butcher 2011; Aliquot 2009, no. 59). However, the social distinction and representation of the political elite in a local guise, the roles played by actual local religious specialists, and an assumed "citizens' performance" at the sacralized place (Andrande 
2013, 223), all seem to fall short as a way of approaching the question of how such space was part of the construction and negotiation of identities.

The two large temple buildings at Niha frame the river and lie close to a spring that flows year-round. The smaller Temple B, in north-south orientation, is about $10 \mathrm{~m}$ long, while the larger Temple A, in east-west orientation, is $20 \mathrm{~m}$ long, with a staircase and platform extending it a further $20 \mathrm{~m}$ to the east. Temple A is the more recent construction (2nd century $\mathrm{CE}$ ), while the smaller Temple B is older (1st century CE); a third building a little to the northwest of Temple B cannot be dated (Yasmine 2009; 2013).

The finds at the site include altars or bases with dedicational inscriptions and relief images, a bronze votive hand, and some fragmentary texts (IGLS 6, 2928-2939). The set of gods venerated here often appear together in the Near East. A pair of highest gods is formed by Dea Syria Nihathena / Atargatis (IGLS 6, 2929; Fig. 3) and Had(a)ranes (IGLS 6, 2928; Fig. 3), while the image of a young male god (Mercurius or Dionysos) might have completed a triad (IGLS 6, 2933 with pl. 45; Kropp 2010) comparable to the triad attested at the sanctuary of Heliopolis/Baalbek some $30 \mathrm{~km}$ to the north. The findings provide a startingpoint from which to ask about the provenance and social or religious identities of the inhabitants of the village, the users of the sacralized place (cf. Rey-Coquais 1981, 171; Rey-Coquais 1992, 258; Krumeich 1998; Butcher 2011).

An altar or base found in Temple B (IGLS 6, 2928, 2nd century CE?; Fig. 3; Hajjar 1990, 2262) mentions a woman active at the sacralized place. The virgin Hochmaea followed the order of the god Had(a)ranes and pursued an ascetic lifestyle, not eating bread for twenty years. The altar is decorated on one side with an image of Hochmaea, wearing a veil and a fillet around her head; ${ }^{8}$ on another, the seated god is depicted flanked by bovids (?) (IGLS 6, $2928 \mathrm{~A}$; Fig. 3). Hochmaea dedicated this altar/base as the fulfillment of a vow.

The same woman is mentioned on a bilingual stela dedicated by the veteran Sextus Allius Iullus that describes her function in the sanctuary (IGLS 6, 2929; Fig. 3): In the Latin text she is the prophetess (vates) of the Dea Syria Nihathena. The Greek line tells the reader that she was the parthenos of the thea Atargateis, synonymous with the local Dea Syria, and that she lived for a hundred years. The monumentum reminds the viewer of a grave stela in form and formula, but Sextus, a veteran and Roman civis, uses it to honor the vates

8 It is common to depict women with a veil covering the head (e.g. on portraits on grave stelae, Skupinska-Lovset 1983). However, the thick fillet around her head might point to a priestly sign (and not only to an "Eastern" dress); cf. the description of a soothsayer by Hilarius, Amm. Marc. 29.1.29 torulo capiti circumflexo. 

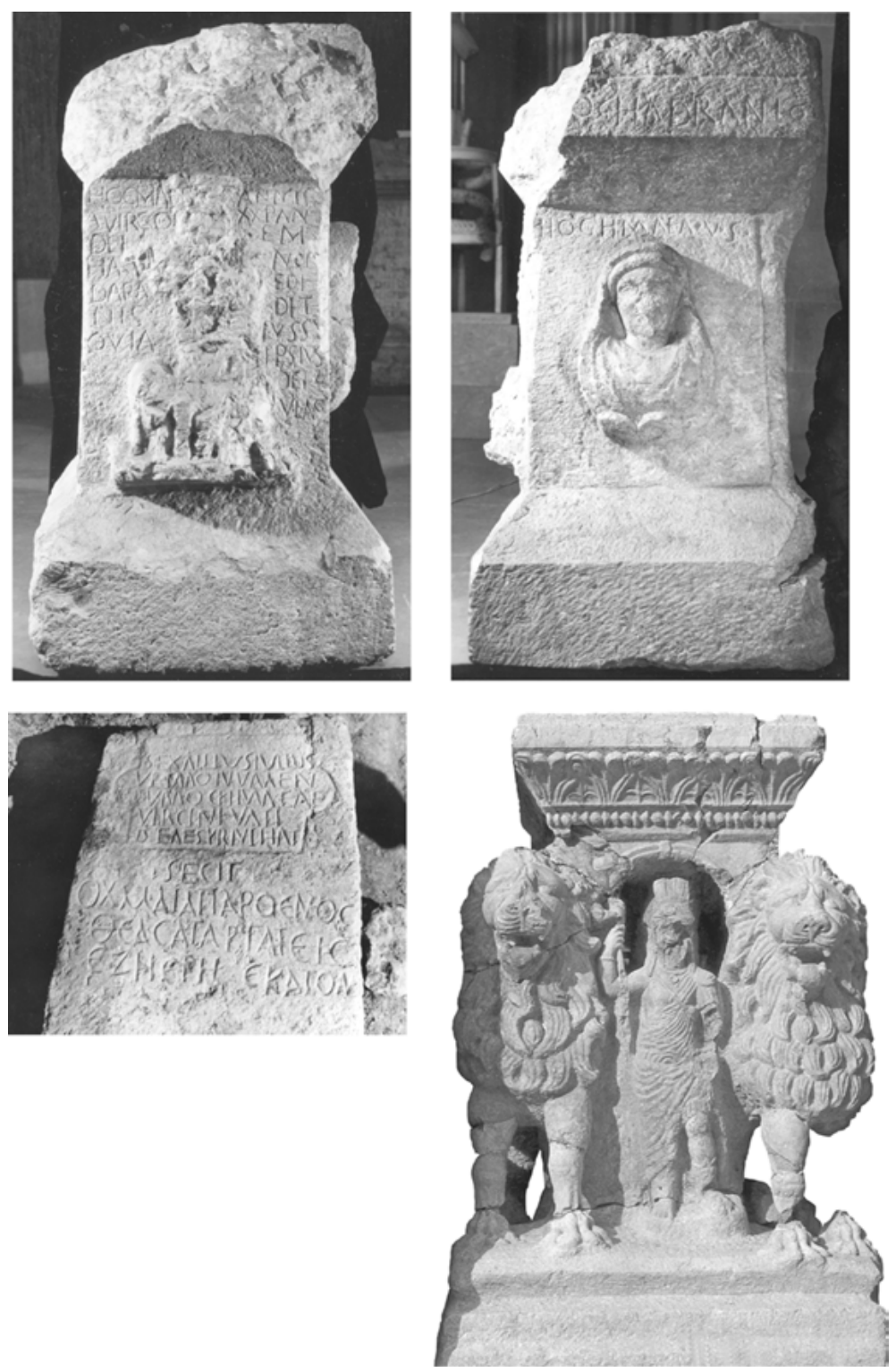

Fig. 3: Altar dedicated to Hadaranes by Hochmaea (top). Dedication by Sextus lullus to Hochmaea (below left). Altar to Dea Syria Nihathena/Atargatis (below right) (Aliquot 2009, Fig. 55. 56. 49. 62). 
or parthenos Hochmaea rather than a dead woman, reconfirming her extraordinary prophetic abilities (cf. Butcher 2011, 460; Lott 2017, 209).

The two agents, Hochmaea and Sextus, both identify themselves with the place through their connections to the local deities. Sextus proclaims Hochmaea's abilities as an "intuitively acceptable agent” (Lott 2017, 210), which makes her a person of reference at Niha. He sets up his dedication in both Greek and Latin so that not only locals but also non-locals (Romans serving in military or administrative capacities) will be able to understand it.

Hochmaea is related to two deities: Hadaranes and Atargatis/Dea Syria Nihathena. The female deity appears under her Latin name of Dea Syria, with her epithet derived from the location of the temple - Nihathena. The Greek Atargatis has its roots in the Semitic word for a widely worshipped goddess in Western Asia, but is not specified with the epithet of the place. The god Had(a)ranes is known only from Niha and Deir el-Ahmar, a settlement $15 \mathrm{~km}$ north-west of Baalbek (IGLS 6, 2908 Latin, cippus from the temple). ${ }^{9}$ Had(a)ranes' depiction (Fig. 3) is analogous to that of the male highest god that appears in many forms throughout ancient Western Asia. However, he is flanked here by lions rather than the bulls that would accompany Zeus Heliopolitanus. Hadaranes is a local god with his own character, not a Heliopolitan god with another name (Cumont 1912). ${ }^{10}$ The way in which Atargatis is depicted is also iconographically distinct from depictions of the Heliopolitanian Venus: on the relief on the altar, she is flanked by lions, not by sphinxes (Kropp 2010, 242 with n. 178-179; Hajjar 1990a, 2522), which ties in well with the local character of the high goddess as Nihathena.

At what was presumably almost the same time as Hochmaea was active at Niha, the priest Narkisos, depicted on the ante of the stairs to Temple A in his priestly dress, identifies himself as bouleutikos of Hierapolis/Baalbek, showing a relation between the place and the huge sanctuary in the plain of Beqaa, once also part of the territory under the administration of Berytus (Rey-Coquais 1987, 200-207; Krumeich 1998; IGLS 6, 2935). ${ }^{11}$ However, his role as an agent in the sanctuary remains underdetermined in comparison to that of Hochmaea. His dress - the pectoral, crown, and offering gesture - represents him as a religiously active man. Hochmaea chooses to relate herself to her religious function in the text and in the image, while Narkisos mentions in the text his

9 The Heliopolitanian Triad was also venerated at Deir el-Ahmar (IGLS 6, 2909).

10 A marble table dedicated to Atargatis was also found at Niha, Rey-Coquais 1987, 206; Kropp 2010, n. 182.

11 Bouleutikos could label an honorary decurio at Heliopolis; cf. Rey-Coquais 1987, pl. 4,1, unpublished inscription on an altar/base. 
political role and his iconography attests to his religious function. Tiberios, the artist of the priestly relief, is, in turn, keen to tell viewers about his own priestly role as well. Another priest is depicted on a large stela (c. $2 \mathrm{~m}$ high, Seyrig 1961, 131-132, pl. V,3), dressed in a manner comparable to Narkisos but with no additional epigraphic text.

Priests and prophetesses as religious agents for Dea Syria Nihathena do not appear with the tria nomina but, rather, with their Greek or Semitic names and in "autochthonous" costumes that say nothing about their civic status (ReyCoquais 1987, 198-207). By contrast, a clear relation not only to the local goddess, but also to some sort of civic entity, is established by the colonists of the pagus Augusti in a dedication found on a tabula ansata of uncertain date (IGLS 6,2936, pl. 45). Taking together the dedication of the statue of the young male god by a Roman citizen with the tria nomina Julius Apollinaris Cels(inius?) (IGLS 6, 2933) and the dedication of the inhabitants of a colonia for an emperor (IGLS, 6, 2937, 2nd century CE, pl. 45; colonia Berytus, see Millar 1993, 178), we encounter a number of Roman institutions and people related to them at Niha. However, they are clearly distinct in what they dedicate and how they do so. For example, a Roman citizen has left a dedicational inscription on one column shaft; it is the only inscription at the site which dedicates something pro salute of an emperor (IGLS 6, 2938).

A quite different reference to identity and affiliation is presented on another altar/base which bears a relief and a number of inscriptions (IGLS 6, 2939). Eutyches offers this object in his role as a (non-religious) professional. The imagery shows a rider/messenger and his horse or donkey, with the text giving his profession as koulso(r). Above the image, on the moulding of the base, (probably) (Iou)ill(o)s added that he fulfilled a vow for the salvation of his oikeia and his children. ${ }^{12}$

On the other sides of the altar/base, it seems that other people have added their own inscriptions, since they differ in letter form from the two inscriptions mentioned above. On the left side, a certain Gaianos, wishing to be commemorated (mneste), describes himself as "the one who works with foals". The rear side is covered by an inscription dedicated by a man (Maranas or Maralas?, see Mouterde 1934), again with the formula mneste. He specifies himself as paranymphos, best man, of Ioullos Mneros. ${ }^{13}$ On this altar/base, the individuals identify themselves by referring to their professions or their

12 I see neither a reason for interpreting the familia as stationarii (Mouterde 1934, 69) nor as focaria (Rey-Coquais IGLS 6, 2939, p. 206).

13 Paranymphos as a religious official is attested at Amathus, Hermary 2010, 129-130. 
relations to their family, friends, or colleagues. In contrast to Narkisos, both Sextus and the people in the inscription of the pagus prefer to mention their occupations or professions rather than their roles in the military or civic systems (pagus, veteranus). That they form a unified group is established by the fact that they appear together in this image-object, and the object itself is located and visible in the sanctuary at Niha. The Greek formula mneste ("remembered be X"), which derives from the Aramaic formula "for the good remembrance of X” (Gudme 2013, 91-134), is used in two cases, adding a temporal dimension to the place. Place-making is enabled by the text on the altar/base, since it stands for an act of remembrance (Casey 1996, 26): Everyone who reads the words is urged to think of those who commissioned the inscription. These inscriptions, by different scribes and on different sides of the altar/base, establish relations between people, their roles, the location, and the deities at Niha, and sacralize the place through the religious practice of calling on passers-by to "remember".

From the necropoleis at Karak Nouh comes a stela of a Roman citizen that sheds valuable light on the differentiations individuals made in their selfascriptions: Q. Vesius Petilianus was flamen and decurio at the colonia Berytus, and also quaestor for, most probably, the same colonia, thus showing off a double affiliation, encompassing both his loyalty to the Roman emperor and his Roman civic status (IGLS 6, 2942, pl. 48). Yet the location of his grave close to Niha demonstrates his strong connection with the place, since he and his wife chose this location to be buried. In shape and motif, the couple draws also on different traditions: Their stela has a local form, but shows the deceased in a very Roman way, using portrait busts. ${ }^{14}$

In the material depicting and describing human and divine agents at Niha, images predominate over script. The reliefs on the temple and on the altars/bases show users and visitors who might not have been able to decipher Latin or Greek the various agents at the sacralized place: The priests, the deities, the prophetesses, the dedicators, and admirers. Those visitors who were able to read would see a range of relations between the various agents transmitted through the texts (Hochmaea, Sextus, the deities, the group in IGLS 6, 2939), and also between the agents and (virtually present) spaces or groups (Heliopolis, the Roman military, Berytus, a pagus). ${ }^{15}$ This provides evidence for (self- and etic) ascriptions by people present at Niha, all of which refer either to the deity of the place or to the

14 Rey-Coquais 1987, 204 with n. 47 emphasizes the high number of grave stelae adapted to Roman models.

15 The problematic interpretation of the pagus Augusti at Niha cannot be dealt with here; see Millar 1990; Rey-Coquais 1987; Aliquot 2009, 39-69; Hošek 2012, 131-147. 
place itself by locating a piece of their life (or death) there. Those in a religious office emphasize autochthonous characteristics (Hochmaea, the priests). At the other end of the scale, Narkisos, for example, alludes to other places, such as Berytus or Heliopolis. The human agents and both real (perçu) and virtual or imagined (vécu) spaces meet at the sanctuary of Dea Syria Nihathena and Hadaranes in the 2nd/3rd century CE in the form of their dedications, images, and inscriptions. Their identities, understood as systems of references and relations between individuals or groups and places, are expressed and communicated in the way that their objects and inscriptions are arranged within the place.

This approach to interpreting the agents, objects, and spaces at Niha goes beyond the search for a "Roman" or "indigenous" identity (Freyberger 1999; Krumeich 1998), accounting, rather, for an identity that is distinctively local. Even though Butcher (2011, 460-461) nicely disentangles the power relations and identities of the individual agents at Niha, he invokes "a place to affirm an ancient 'native' identity" by arguing that Narkisos made use of a presupposed "nativeness" of the sacralized place. By including not only common identity markers such as provenance, dress, family, or social status, but also emphasizing what people themselves relate to in their communication with deities and humans, we come closer to the local, communal conglomeration of personal or group interests, of families, functions, and professions. Under the umbrella of Dea Syria Nihathena, the goddess of this place, the activities - visible in the shape of dedications, buildings, inscribed vows, and depictions - establish a local system of references, a local identity that forms part of people's individual identities. By setting up a dedicational inscription or sculpting a relief, people localize themselves within this place and sacralize it. They refer in script and image to other places or institutions (colonia Berytus, Heliopolis, Roman military, portraiture), which points to the rhizomatic web of people and places pinned down at the place where the Dea Syria Nihathena resides. There is not only one "there" but various "theres" at Niha (cf. Massey 2005, 140).

Apart from these rather virtual spatial relations, the "production of space" through religious practices could also have occurred at the place: While we do not know where Hochmaea's altar/base and Sextus Iullus' stela stood, those able to read would be able to relate the two to each other, even over a distance. The descriptions in these two inscriptions refer to religious duties and agencies. Narkisos' inscription, by contrast, is positioned on the ante of the stairs leading up to the temple while another priest had a stela that was not part of the building but was still hardly mobile. They and their images had a "sacralizing effect", since their appearance and attributes show them as religiously active. The base/altar, with its inscriptions by people related through profession or friendship, seems to have been an object that was in continuous use: new lines 
were added in order to establish a relation both through the placement of the inscription and through social aspects.

The density of and relations between the buildings, human agents, and objects within the sanctuary, the chronological coincidences and practices, the various roles and functions played by agents in establishing community (or distinction) around the very local divine agents, all contribute to making this space a lived religious space.

\subsubsection{Hosn Niha: religious team work}

It is not only the density at the sacralized places that is important, but also the density of the places: The closest sacralized place to Niha is Hosn Niha, $2 \mathrm{~km}$ up the valley to the west (Fig. 2; Newson and Young 2015). This place also belongs to a very local deity. The settlement spreads along the slope and its inhabitants would have been able to make use of the fertile soil that lined the valley bottom. On three terraces on the northern slopes, various buildings mark a sacralized place that is roughly contemporaneous to Niha: A large temple from the 2nd century CE; a smaller building with a well; and several simple rectangular buildings along the southern side of the terrace. ${ }^{16}$ On the other side of the valley, a building, divided into two rooms and with two altars in front of it, has been excavated and marks the point at which a second road crosses that which comes up from Niha. ${ }^{17}$ Water is abundant here and springs feed a kind of well-house in the sanctuary, as well as the creek running down to Niha. Apart from these connections, the sanctuary of Hosn Niha is distinct in so far as it has different functional parts and belongs to a different local god.

The buildings, temple, well-house, stock rooms (?) and terraces have not yielded any finds that would allow us to draw conclusions about the rituals that took place there. The only finds are a part of a base/altar and the inner part of a hamana, a kind of block surrounded by columns (Krencker and Zschietzschmann 1938, Fig. 190; 189). The rectangular hamana-block is decorated with niches at each side, formerly containing statue(tte)s, with an inscription running above one of the niches (IGLS 6, 2946, $2.5 \mathrm{~m}$ high). The inscription speaks about property and revenues that the local stakeholders administered

16 Cf. F, G, H on the map of Krencker and Zschietzschmann 1938, 122-137, esp. pl. 60; Aliquot 2009, no. 60; Yasmine 2009; 2013 for a refined chronology and the layout of the place.

17 Krencker and Zschietzschmann 1938, 135-136; the building at the crossroads is denominated H0O3 by Newson and Young 2015. 
for the god Mifsenus and the vicus for which he is responsible. They were the cultores dei Mifseni in the spatial and economic realm of the god Mifsenus, who acted collectively, if not necessarily harmoniously. Four of the people who dedicated the hamana and were responsible for the finances have Latin names while five have Aramaic names. Apart from this differentiation, it is noteworthy that no one mentions a father's name. They do not refer to families and ancestors at all, but only to their group, their function and their god. Like Dea Syria Nihathena, this god also bears a toponymic name marked by the ending -enus. It was in terms of their relation to him and to the place that these nine individuals chose to present themselves.

One of Mifsenus' officials probably identified himself as veteranus (1. 4), while the other three who bear Roman names appear without specification. How Roman these people were in comparison to their Aramaic-named colleagues remains an open question, since onomastic characteristics cannot, contra Rey-Coquais, ${ }^{18}$ be taken as an ethnic identity marker. Just how blurred ethnic boundaries in the region are is made clear in the form and content of the funerary stela of the children of Gaius Claudius Marcellus: two of the three sons of a man with the tria nomina bear Greek names and one a Latin name (IGLS 6, 2940; Rey-Coquais 1987, 203-206). The stela is shaped in the form of a cone, with four more cones engraved in the upper part, which is typical of tomb markers in this region (Kropp 2013, 216-218). If the inscription of the cultores dei Mifseni is correctly dated to the 2nd century CE, the Roman administration of the area will still have been a relatively new phenomenon. Nevertheless, the presence of individuals from a wide range of places, including the Roman Empire, and with various provenances, languages, or fashions was nothing new in the valleys of the eastern Lebanon.

What is more interesting for understanding the spatio-relational dimension of identity is that the cultores appear as a collective of nine men identified only by their names - no family or communal affiliations are given. The kind of identity they chose to show becomes clear from the spatial setting in which the inscription is located: placed in the agricultural terrain of the god Mifsenus on the slopes of Jebel Sannine, they appear as his vicani without reference to families or status. The other aspects of identity simply do not play a role in this context. More important is their individual identification with the god, his economic performance, the vicus, and the land (Hošek 2012, 132-136). Through their connection to a particular architectural shape and a visible monument in the god's place, these individuals manifest their loyalty and services to the deity.

18 See IGLS 6, 2946, p. 211: "l'association ... des élements autochtones de la population et des colons romains". For a differentiated view on onomastics, see, for example, Isaac 2009. 
The term cultores can be treated as parallel to katochoi, a group of people responsible for the cult attested at Baitokaike and Har Senaim (IGLS 7, 4028; Dar and Kokkinos 1992, no. 1 with Fig. 3; IGSL 11, A/2). This group served in the financial and economical administration and in the performance of the sacralized places. It is, thus, unsurprising that a certain Sophron holds the office of oikonomos at Hosn Niha (IGLS 6, 2947), most likely a position related to the financial administration and investments of the cultores. ${ }^{19}$ The inscription and reliefs on the base here are mutilated, so that only Sophron stands out as a clearly male name among a number of other fragments.

In comparison with Niha, Hosn Niha appears to have served a different function, even though the evidence that has survived might distort the picture. Property, economic success, and organization prevail here under the auspices of Mifsenus, the god of this area alone. Ritual dress or a civic office is not the focal point of reference for any identity building here. Rather, this role is fulfilled by the terrain and the god of the place. The agents appear only in relation to him, and no other ascriptions or affiliations are applied in the services they perform for him. We can detect here a functional split, despite their proximity, between the sanctuary down the slope at Niha and that at Hosn Niha, which goes along with a clear distinction in the affiliations and allocations of the residents. People make no references to places and entities outside the terrain of Hosn Niha. Even though the territories and families must have overlapped, or at least neighbored one another, and some tasks, such as water regulation, could only have been resolved on a broader inter-communal scale, the responsibility for certain areas and the people associated with those areas rests with a certain local deity. At the risk of overinterpreting the evidence, the hamana block at the sacralized place with its inscription naming the cultores in service of the god might be interpreted as both a part and a result of "the lived space" in the valley and community of Hosn Niha.

19 Sophron may also feature on an altar/base, where a person is depicted with a veiled head in frontal view, either bearded or covering the lower parts of the face with the veil. Beside him or her, a child at the height of the shoulder is visible in profile, holding a tabula with Sophron written on it. More veiled figures, of whom only the heads are preserved, appear on the right side (cf. Krencker and Zschietzschmann 1938, 136-137). In case the two Sophron are identical, he appears in a financial and a religious office. 


\subsubsection{The upper and the lower Temnine: next valley, next god}

If I am right in assuming a very local self-ascription of agents at Hosn Niha (through the god Mifsenus) and at Niha (through a concentration of external spaces and social entities represented by agents, texts, and images), then it makes sense to expect this small-scale religio-spatial identity pattern to continue on the slopes of Mount Lebanon.

Connected with Niha and Hosn Niha by a necropolis, we find in the valley to the north the sacralized places of Temnine el-Fouqa (Fig. 2) and Temnine elTahta. The upper Temnine (el-Fouqa), $1.5 \mathrm{~km}$ northeast of Niha as the crow flies, could be reached in less than an hour's walk. Here, a spring is enclosed by a vaulted construction dug $4 \mathrm{~m}$ deep into the slope. Two columns in antis mark the entrance. Inside the vaulted room, niches remain visible on three sides, as do a raised area running the length of the rear wall and a manhole for reaching the water in a deep well. The niches may have housed images of gods or just served a decorative function. The religious character of the water and place may be deduced from a rather worn relief on a cubic altar/base found close to the nymphaeum. It shows in low relief a female deity with a curled, wavy object in her right hand. ${ }^{20}$ From the knees down she merges with the pedestal on which she stands, as is common for Syrian gods. Given the poor state of preservation of the relief, all proposed names for the depicted deity must remain assumptions. Nevertheless, if we take the curled object to be a snake, then this iconography would point towards Hygieia if interpreted in a GrecoRoman context, perhaps suggesting that the water was considered to have beneficial properties.

There are no traces of human agents at the spring of Temnine el-Fouqa. However, given the presence of the many tomb stones and inscriptions found between the ancient villages of Niha, Hosn Niha, and Temnine el-Tahta and elFouqa, we can assume a landscape on the slopes of Jebel Sannine with a considerable number of inhabitants - either living or dead (IGLS 6, 2940. 2942-2944). The accessible water at Temnine, the close-by necropoleis, and the villages and fields represent the layers of the espace perçu and the espace vécu of Lefebvre. Forms of lived space are represented by natural phenomena, anthropogenic organization of natural space, the ascription of meanings to places, and the formation of memory, which latter is closely related to various aspects of identity through its shaping of status, family, ancestors, and, finally, also divine agents.

20 www.facebook.com/lebanonbaalbekmegaliths/photos/pcb.1686869351578412/ 1686868651578482/?type=3\&theater, retrieved 5th of November 2018. 
In the lower Temnine, a temple was dedicated to Jupiter Optimus Beelseddes (Krencker and Zschietzschmann 1938, 138-140, pl. 6; Aliquot 2009, no. 58). The Latin inscription IGLS 6, 2925 reads I(ovi) O(ptimo) Beelseddi, addressing the Latin high god Jupiter with the topographically descriptive Semitic epithet, Belseddes. Belseddes can mean a Baal of the mountain or of the field. The inscription was set up by three people with Latin and Greek names. ${ }^{21}$ The Jupiter of this mountain - the Jebel Sannine or, from a more localized perspective, its eastern slopes - seems to be an important deity with whom the people of Temnine were able to identify.

Temnine also had another local god, Zeus Thamaneitanos. An inscription on a small bronze tablet refers to the place and people of Thamneita, for which he was responsible (IGLS 6, 2960; Fig. 4). ${ }^{22}$ This was found at Zahle, c. $8 \mathrm{~km}$ to the southwest of Temnine, and can be attributed to the village, the name of which was later Arabicized (Aliquot 2009, no. 58). Lucius Servilius Eleutherus offered this plaque to be fixed in a wall or on a stand.

Scholars of the history of Rome's Western Asian provinces agree that there was some degree of ongoing integration and mixing of "Roman" people, i.e. Western and Central Mediterranean people, with inhabitants of the mountains and plains of Lebanon and Syria after the first colony at Berytus was founded in the 1st century CE. A close examination of the sanctuaries in these areas and their boom in the 2nd century shows the necessity but also the success of the locals in negotiating their belonging to a place and, ultimately, to a broader political and economic unit. We find Roman names and marks of status reflected in the texts, but the dedications at these places are offered up to local gods. Of course, a reorganization of land ownership was taking place during this period and there were, perhaps, more people to be fed by the existing cultivated land. However, for many inhabitants, the appropriate course of action seems to have been to build a strong relationship with the already strong local deities by using their sanctuaries (Hošek 2012, 199 - the enlargement of the territory of Augustan Berytus).

Things are rather different at Ain Housbay, c. $12 \mathrm{~km}$ northeast of Temnine and close to Beit Chama (Aliquot 2009, no. 56, Fig. 171). Nevertheless, the situation here also reflects the various layers of perception and construction of inhabited land. Here, IOMH is the addressee of a votum by Quintus Baebius Rufus (IGLS 6, 2923; Hošek 2012, 135-136) given in an inscription on the curved

21 Another dedication, this time solely to Jupiter (IGLS 6, 2926), was raised by a libertus. 22 See Seyrig 1954, Fig. 3, with correct measurements: 7 x 3.6 x $3 \mathrm{~cm}$ (with provenance from Arabia). 

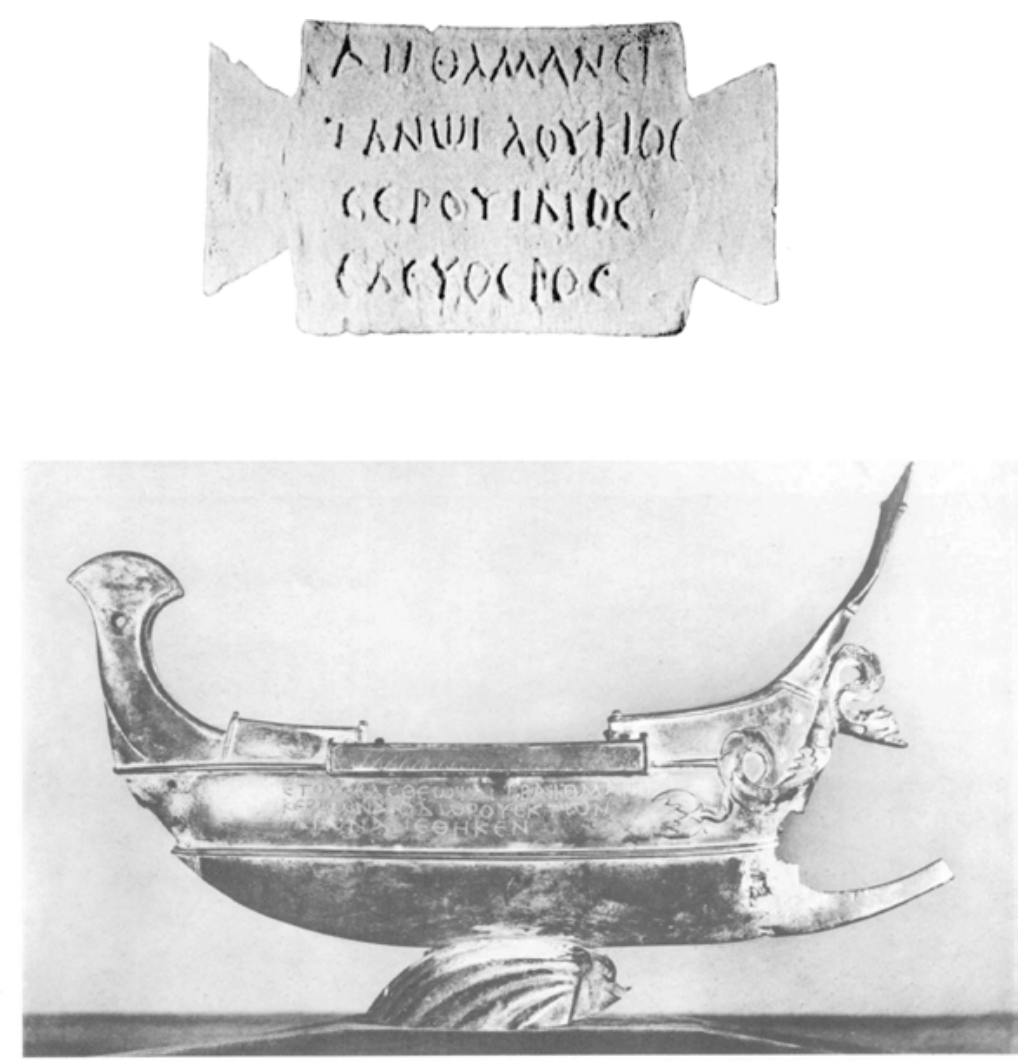

\section{ETOYCB人C $\theta \in W \| \Delta I \% B A|\theta M A P h|$ KEPDWNDIOD WPOYEKTWN $\triangle I W N A N \in \theta H K \in N$}

Fig. 4: Bronze tablet with the inscription to Zeus Thamaneitanos (top). Bronze ship dedicated to Zeus Baithmare (below). (Seyrig 1954, 128, Fig. 3; Seyrig 1951, pl. 9 and p. 101).

moulding of the barrel-vaulted nymphaeum. The god in this case is the Jupiter worshipped at the supra-regional sanctuary at Heliopolis. The common explanation for other instances of $I O M H$ in the Beqaa and the Lebanon mountains is the domination and territorial claims of the Heliopolitanian sanctuary. However, the spatial approach outlined so far shows that it was, in fact, the local deities and religious identities that provided points of references for inhabitants of this area. 
The evidence from Ain Housbay shows that it was the close personal connection to Heliopolis of this particular donor that instigated the choice of this god rather than any generalized status that this god had (other Baebii IGLS 6, 2719; 2743; 2964). Baebius identifies himself as Roman, and as related to Heliopolis and its male highest god; local identities do not play a role for him in this case.

This outlier aside, each place was inhabited by an individual god: Zeus Thamaneitanos is the god of Temnine; Jupiter Beelseddes is also present at Temnine el-Tahta; the Dea Syria Nihathena was responsible for the village of Niha $1.5 \mathrm{~km}$ away; the Deus Mifsenus is the god at Hosn Niha. Each deity in a radius of $5 \mathrm{~km}$ reigns over a certain defined area and is relevant for certain groups of people that are active in the area, and each deity is ascribed certain specific competences.

The small-scale religio-spatial pattern that emerges may be related to a complex socio-political constellation, driven by the varying economic interests of the people in the Beqaa plain and on the Jebel Sannine. Generations of families seem to have integrated newcomers (Rey-Coquais 1992, 252; Hošek 2012, 130-159), looking for ways to cope with the various groups and places they belonged to or could belong to, and ways to manage the changing social relationships. It is possible to interpret the growth and reorganization of the sacralized places mentioned so far as both a part of, and a result of, these processes: people lived on this land, had ancestors' graves to visit, fields to cultivate, and gods to worship. The reorganization that began in the 1st century CE encouraged the use of practices that could help the individual position him- or herself within the various changing social groupings. The places and names of the gods remained local (in contrast to the developments at Heliopolis, see Hošek 2012, 128-148; Kaizer 2016), and in turn sacralized them by dedicational practices that maintained and fostered their local character. In seeking support, and in establishing or negotiating relations, people were able to rely on these closeby deities. They "lived" these spaces in daily practices (perçu), in their ascriptions of transcended responsibility (vécu), and in the construction of an imaginative mind-map of the flexible, dynamic spaces around them.

Underpinning locality and local references and identities only makes sense when there is a non-local environment against which one can be distinct. Hence, the Dea Syria Nihathena is only valuable if there is a Mifsenus and Zeus Thamaneita. Aliquot $(2009,62)$ is right to dismiss the still common opinion that all these gods are basically forms of the Heliopolitan Triad (Ronzevalle 1937; Seyrig 1961; see also Kropp 2010; Kaizer 2016), which supposition is a retrospective construction rather than a contemporary fact. These gods and goddesses are distinctively local and are closely bound to specific places. Only where Zeus (or Jupiter) Heliopolitanus is named as such does the name refer to Baalbek, as the example 
from Ain Housbay demonstrates (Aliquot 2009, Fig. 108). In addition, Romans or Roman colonists at Yammoune (Aliquot 2009, no. 52; IGLS 6, 2918) and Karak Nouh (IGLS 6, 2953; 2955 Gnaeus Iulius Rufus) speak of their connections to Heliopolis or Berytus, connections that might also be mirrored in architectonic similarities between temple architecture at Heliopolis and, for example, the temples at Niha and Hosn Niha (Yasmine 2009).

On the one hand, addressing a local god with a localizing epithet makes it clear to where the divine agent and his or her human counterpart belong. On the other hand, it is only necessary to name the locale if either outsiders or non-locals are present and if one feels the need to distinguish oneself from them, as with the need to distinguish one's own village identity from that of the next village over. Since many of the temple areas were also heavily involved in cadastral, economic, and redistributory services (Hosn Niha, Ferzol; IGLS 6, 2951), ${ }^{23}$ the denomination of a local divinity responsible for the local community makes even more sense. The locale is the background against which the individuals and families of one community could make themselves distinct from another.

\subsection{Village, community, and deity in the Mount Hermon region: small environmental and social boundaries}

\subsubsection{Zeus at Baithmare - a local Zeus as identificational model}

Further south, on the northern slopes of Mount Hermon, we have only little, yet still rather promising, evidence of local deities and the relationships they had with local residents. Theos Zeus Baithmare received here a bronze ship, transformed at a later point into a lamp, given by Kerdon, son of Diodoros (Seyrig 1951, 121/122 CE, era of Sidon; Fig. 4). The find spot is about $5 \mathrm{~km}$ away from a village named Bab Mar'a (IGLS 6, 2989). I follow Seyrig (1951,102) in connecting the Zeus with the toponymic epithet Baithmare to this village, which is about $5 \mathrm{~km}$ from the first "appearance" of the ship in Aithenit, a village $5 \mathrm{~km}$ to the south, roughly between Sidon and Caesarea Philippi.

Bab Mar'a is a hotspot for finds: Others in the area include a statue of a cuirassed god and the marble head of a female ideal sculpture, probably also a deity. Moreover, a jug, a statuette, and a lamp, as well as pieces of chains - all made from bronze - have been found (Seyrig 1951, 120-123). There is no trace

23 Cf. IGLS 6, 2734. 2735 to Mercurius at Sheikh Abdallah close to Heliopolis. 
here of a sacralized place dedicated to this Zeus, and we cannot be sure to what contexts the described pieces belong.

Even if these objects do not allow for far-reaching interpretations, we can still say with some certainty that the place is more than just a sacred place at the border of the territories of two cities, Sidon and Caesarea Philippi. It is also more than just an attestation of the "vitality and independence of village life". ${ }^{24}$ If we examine the evidence from the perspective of place-bound identity and lived space, the place offers an important point of reference for the people living there. A local high god is the point of reference and identification for those worshipping him, and a sign of distinction from other gods and their places in the area. The pieces of sculptures, the metal objects, and the dedication to Zeus Baithmare from the village at the southern end of the Beqaa plain thus not only attest to the community of the village with its god, but also to ways in which people engaged in making their living there communicated and negotiated - under the auspices of Zeus - local demands, needs, and identities. The local god offers a powerful basis for interacting with the cities along the coast (Sidon and Tyros), or in the Hermon (Caesarea Philippi) or Bekka (Heliopolis) areas. Its position on the border with the area of Caesarea Philippi (hence, with Galilee) might lead one to call it the border sanctuary of a local Zeus, while the proximity to Sidon might be thought to indicate that it is a territorial "extra-urban" sanctuary of the city. Yet these terms grasp only one aspect of the character of such a place of a god: sacred places in the ongoing process of sacralization through rituals are locales through which a city can mark off its territory. However, this interpretation takes only partial account of the people living in these places. The continuity of individuals and families living at certain places might be stronger than the shifting constellations of territorial claims. The sacralized places are lived spaces, formed by and containing traces of stories, relations, memories, etc., which are enacted through the worship of a local deity, in this case Zeus Baithmare on Mount Hermon. The place of Zeus Baithmare, his village, and the community for which he is responsible, is comparable to the sacralized area of Dea Syria Nihathena. The concentration, and hence the point of communication and negotiation, is created by the god or goddess, his or her worshippers, and the place in its larger environmental and political setting. ${ }^{25}$

24 Millar 1993, 287, explaining thus the density of sacralized places in Lebanon.

25 People at Haloua in the northwestern parts of the Hermon (Aliquot 2009, no. 89) worshipped another local Zeus. On the meaning of kyrios as acclamation also for Zeus in GrecoRoman dedications see Belayche this volume. 


\subsubsection{Leukothea at Rakhle and at Segeira - the integrating divine figure}

Close to Baithmare and its gods lies a place and village under the protection of the Leukothea of Rakhla, thea Leukothea Rachlas (IGLS 11, 23). The ancient village is situated on the northeastern slopes of Mount Hermon (Dar 1988; Dar and Kokkinos 1992; Fig. 1). Findings which point to the deity Leukothea come from the northeastern parts of the modern village (Krencker and Zschietzschmann 1938, 223-226; Aliquot 2009, no. 106). ${ }^{26}$ The goddess with the Greek name is denominated not with a local but with a societal epithet - the genitive of the community to which she belongs, or which belongs to her (IGLS 6, 23). The inscription dates to 268/69 CE and mentions two hierotamiai of this goddess using some silver from the deity's property for the doors of a building (Sartre 1993, 54-55, no. 3; IGLS 11, 23; Bonnet 1986). Thea Leukothea, without the local epithet, received another dedication in the 1st or 2nd century (IGLS 6, 21). Earlier, in $60 \mathrm{CE}$, there was only a thea venerated at Rakhle (IGLS 6, 20. 22). In the second inscription, it is the plain mention of thea that can be interpreted as a localized form of the goddess Leukothea, even though the stone in which the text was inscribed is not preserved, but stood somewhere at Rakhle. Hence, the thea is referred to through the position of the dedicational text and is associated with that place. The earliest inscription from Rakhle, IGLS 11, 20, dated to $60 \mathrm{CE}$, refers to a personalized deity - thea Moithou. This strategy of making deities unique by "personalizing" them is common in, for example, southern Syria (cf. Theandrios at Kanatha, Aliquot 2008, 287). The inscription to thea Moithou speaks about a building in her sacralized place, while the subsequent inscriptions (IGLS 6, 21-30) speak about renovations; money was not a problem here, it seems. We can infer from these texts that the goddess of Rakhle not only had personnel responsible for overseeing her cult, buildings, and visitors, but also for managing the property of the deity. As the deity of the village's community, her property is identical to that of the villagers.

From the northern slopes of Mount Hermon (Qalaat Jendal) originates an inscription in which Leucothea Segeiron features at the end of the text on a large marble slab (Fig. 1. 5; IGLS 11, 39). Where exactly ancient Segeira was located remains an open question (Aliquot 2002 on the location, esp. p. 246). However, we can see that people from this place venerated the goddess Leukothea as the goddess of the villagers, the social body of the place (Bonnet

26 The deity to whom the remains of a second temple building were dedicated is not clear. 


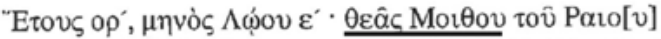

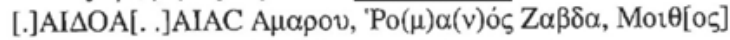

$\mathrm{A} \beta \imath \delta \alpha \alpha v \alpha \varsigma, N \varepsilon \tau \imath \rho o[\varsigma] ~ \Sigma i \lambda o v \alpha v o v \hat{,}, \Sigma v \mu[---]$

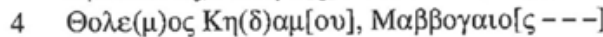

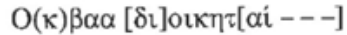

IGLS 11, 20 (60 c. CE)

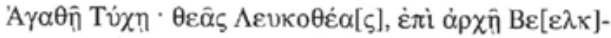

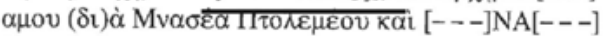

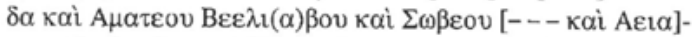

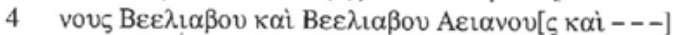

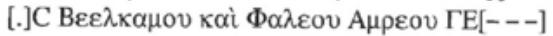

$\delta$ Lotkn[ $\tau \hat{\omega} v---c a 16$ lettres - - -]YCEI $\Delta \mathrm{O}[---]$

IGLS 11, 21 (1st or 2nd c. CE)

$\Theta \varepsilon \alpha \hat{\varsigma} \Lambda \varepsilon \cup \kappa o \theta \varepsilon \dot{\varepsilon} \alpha \mathrm{P \alpha}-$

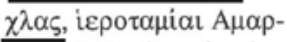

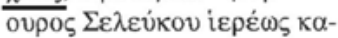

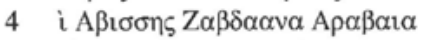
$\tau \dot{\alpha} \lambda \varepsilon{ }_{1} \phi \theta \varepsilon \dot{v} \tau \alpha \pi \alpha \rho^{\prime} \alpha \dot{v} \tau 0-$ iऽ $\dot{\alpha} \rho \gamma v \dot{\rho} \iota \alpha \dot{\alpha} v \alpha \dot{\lambda} \omega \omega \sigma \alpha v \tau \dot{\alpha}$

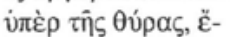

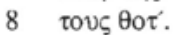

IGLS 11, 23 (269 CE)

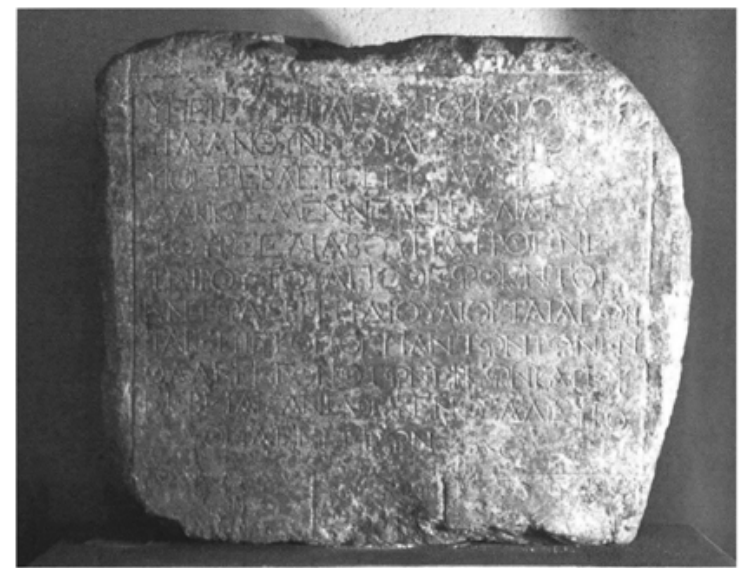

IGLS 11, 39 (early 2nd c. CE)

Fig. 5: Inscriptions of Leucothea from Rakhle (top) and Segeira (below). (IGLS 11, 20. 21. 23. 39). 
1986; Sartre 1993, 57-58; Kaizer 2005). ${ }^{27}$ Since marble is used for inscribing and offering the dedication to the goddess, we can assume a choice and effort on the part of the commissioners and dedicators: marble is a rare and very unusual material throughout this entire region.

Alongside the bias of the extant pieces towards financial issues, another characteristic in the texts is the predominance of certain names, and perhaps the families of the cultic officials. Six inscriptions from the 1st to 3rd centuries CE (IGLS 11, 20-25) feature Amreos/Amaros, Zabdas, Seleukos, and Beeliabos, hinting at a family dynasty of officials. For a certain group of families at Rakhle, the strong interest in the goddess and the village was connected to the responsibility and power involved in the control of the revenues from the property of the deity. Even though other inhabitants of the area and the village are not represented in the epigraphical material (the only image-object is the eagle on the lintel), ${ }^{28}$ parts of the population did their very best to create a longlasting rootedness in that place. What makes the difference here is the local form. In a way that is comparable to Christian saints who have the same name (and comparable functions) wherever they are venerated, the localized appearances gain significance in, for example, the form of pilgrimages, and serve as signs of local identity.

So, why is Leukothea so prominent in these two villages of Mount Hermon during the Roman period ${ }^{29}$ The preference for Leukothea in Syria Phoenice (and Syria) is often explained by reference to the importance of this Greek Mediterranean goddess for women and for seafaring. But this is a Greco-Romancentric view. If we confine ourselves to these mountain communities in the province of Syria, Leukothea is equivalent to the many "localized" Zeuses. We can track down her potential to be used for strategies of constructing place-bound identity in the global setting of a Greco-Roman Mediterranean. In the Roman period, Leukothea no longer appears as a "foreign" Greek goddess, since she has been assimilated to Atargatis. As Lightfoot 2003, 71 states, "Leukothea is attested in a fairly specific area, but even within that her own contexts seem to differ ... So even within her relatively limited compass, it is unlikely that all her local forms were direct equivalents of Atargatis." Leukothea is capable of being the deity of numerous particular spots in Phoenicia and Syria, with epithets giving her local guises in each case. The addition of the village or the villagers to the deity's name

27 The similarity of the dedicational inscription to funerary inscriptions (Aliquot 2002, contrary to Bonnet 1986) might also point to a very local tradition and background.

28 Only one funerary inscription is preserved (IGLS 11, 33) at Rakhle.

29 For all the places in the Lebanon mountains where Leukothea was worshipped, see Aliquot 2009, Fig. 108. 
makes this local affiliation clear: making an offering to this Leukothea is a statement in favor of a certain local community and place.

Religion, and with it the veneration of gods and goddesses, serves to stabilize social relationships and institutions. This explains the strategy of local attributions and affiliations by and for agents. Spatializing religion makes it work on a local level, from which we can then extrapolate to larger societal entities. ${ }^{30}$ Even if a local identification of and with the god or goddess is implicit at all sacralized places, because the deity is present at his or her site, the evidence for the addition of the name of a place or community, an epithet as her or his specification, still implies a wish on the behalf of the local residents to emphasize and display the local divine power.

\section{Spatializing religion and localizing identities as one approach to the archaeology of religion in the Roman provinces of Western Asia}

The examples of the places, people, and gods of the Roman provinces of Syria and Syria Phoenice from the 1st to the 3rd century CE, discussed above in the context of their material and social particularities, demonstrate the close relationship between local identities, lived religion, and lived space in these parts of the Roman Empire. Hence, we can speak of the locally-lived identities of people in the Mount Lebanon, Beqaa plain, or Mount Hermon areas. It is not only the religious dimension of identity building that has become clear through the strong connection of individuals to local deities and their sacralized places, but also the deities' impact on and relationships with groupings and individuals.

In order to maintain my focus on the local character of the deities and their role in establishing and negotiating rather small-scale identities, I have not examined many of the historical, political, and socio-economic dimensions of the places discussed here. The deities and their sacralized places at Niha, Hosn Niha, and Temnine el-Fouqa and el-Tahta are embedded in a small-scale landscape of finely-tuned spatial and functional distinctions. The deities are named after the place, or vice versa (Dea Syria Nihathena), or they are unique (Mifsenus). The small distances between the deities and their places leads to localized

30 What we learn from the spatial approach to religion correlates with results from economic and administrative surveys in the region and corroborates e.g. Millar 1993, 287 (on the independence of village life). 
specifications and demonstrates the desire for local religious points of reference for the people living close by. The example of Leukothea on Mount Hermon demonstrates how a goddess - despite her widely acknowledged competences - features as the local deity, corresponding to the various Zeuses with their own local specifications. Small-scale natural, material, and personal conditions and environments fostered the development of the deities attributed to the corresponding spatial and social entities. As Kaizer 2005, 204 has stated, "religion in the Roman Near East ought to be approached first and foremost from the local perspective."

The need for, and interest in, very local gods lies in shifting borders and the changes in political power and economic relationships in the period between the 1st and the 3rd centuries CE. The net of local divine agents served to stabilize this highly variable environment, and added to their local identity, one of the presumably many identities that people in this area had. Approaching religion in a strictly spatial manner and analyzing religious places as lived spaces contributes to a picture of lived religion in Roman Syria. It acknowledges the local and conveys the narrow interrelations of localities, local religion and local identity.

The combination of a spatial methodology of the lived space and the analytical paradigm of lived religion focuses the lens through which we can view individual religious choices or the choices taken by groups at a certain place in comparison with the choices of other practitioners at the same location, nearby, in a wider area, or lastly in the wider context of the Mediterranean (cf. Sommer 2009). This approach re-locates and contextualizes archaeological evidence of human agents in non-urban, rural areas as a first step towards interpreting it. A narrative of the history of the religion of the Western Asian Roman provinces has to start on this level, before it can begin to deal with sanctuaries and their building history, with supra-regional divine triads, and with the territories that were steered and influenced by cities and their officials.

The perspective of lived religious spaces I have presented here accounts for the situational, space-producing character of religious practices. The approach to lived, practiced, and material religion, complemented with concepts of (the production of) space, enables us to revise overly narrow views of architecturally formed spaces ("temple") within a natural space ("landscape"). It opens up new perspectives on the sacralized places and landscapes in which human and divine agents interact, with the goal of establishing and negotiating bonds and identities, as well as self-world relations. Acknowledging these processes generates a picture of religious practices and places in the distinctive regions of Roman Syria that is dynamic and fluid rather than static. Religious places thus become more than mere dots on a map. 


\section{Bibliography}

\section{Abbreviations}

IGLS 6 Rey-Coquais, Jean-Paul 1967. Inscriptions grecques et latines de la Syrie VI, Baalbek et Beqa'. Bibliothèque archéologique et historique 78. Paris.

IGLS 7 Rey-Coquais, Jean-Paul 1970. Inscriptions grecques et latines de la Syrie VII. Arados et régions voisines. Bibliothèque archéologique et historique 89. Paris.

IGLS 11 Aliquot, Julien 2008. Inscriptions grecques et latines de la Syrie XI, Mont Hermon (Liban et Syrie). Bibliothèque archéologique et historique 183. Beirut.

\section{Literature}

Albrecht, Janico; Degelmann, Christopher; Gasparini, Valentino; Gordon, Richard; Patzelt, Maik; Petridou, Georgia; Raja, Rubina; Rieger, Anna-Katharina; Rüpke, Jörg; Sippel, Benjamin; Weiss, Lara; Urciuoli, Emiliano R. 2018. 'Religion in the Making: The Lived Ancient Religion Approach', Religion 48. 568-593.

Aliquot, Julien 2002. 'Leucothéa de Segeira', Syria 79. 231-248.

Aliquot, Julien 2008. 'Sanctuaries and Villages on Mt Hermon During the Roman Period.' In The Variety of Local Religious Life in the Near East in Hellenistic and Roman Periods, ed. Ted Kaizer. Leiden. 73-96.

Aliquot, Julien 2009. La vie religieuse au Liban sous l'empire romain. Beirut.

Andrade, Nathanael J. 2013. Syrian Identity in the Greco-Roman World. Greek Culture in the Roman World. Cambridge/New York.

Ashmore, Wendy 2004. 'Social Archaeologies of Landscape.' In A Companion to Social Archaeology, ed. Lynn Meskell, Robert W. Preucel. Oxford. 255-271.

Belayche, Nicole 2000. 'L'Oronte et le Tibre: “L'Orient” des cultes "orientaux" de l'empire romain.' In L'Orient dans l'histoire religieuse de l'Europe. L'invention des origines, ed. Mohamed Ali Amir-Moezzi, John Scheid. Bibliothèque de l’École des Hautes Études, Section des sciences religieuses 110. Turnhout. 1-35.

Belayche, Nicole 2007. 'Les dieux "nomothètes". Oracles et prescriptions religieuses à l'époque romaine impériale', Revue de l'Histoire des Religions 224. 171-191.

Belayche, Nicole 2009. "'Languages” and Religion in Second- to Fourth-Century Palestine: In Search of the Impact of Rome.' In From Hellenism to Islam. Cultural and Linguistic Change in the Roman Near East, ed. Helen M. Cotton et al. Cambridge. 177-202.

Blömer, Michael 2017. 'Revival or Reinvention? Local Cults and their Iconographies in Roman Syria', Religion in the Roman Empire 3. 344-365.

Bonnet, Corinne 1986. 'Le culte de Leucothéa et de Mpelicerte, en Grèce au Proche-Orient et en Italie', Studie e Materiali di Storia delle Religioni 52, N.S. 10. 53-71.

Borg, Barbara E. (ed.) 2004. Paideia. The World of the Second Sophistic. Berlin.

Brace, Catherine; Bailey, Adrian R.; Harvey, David C. 2006. 'Religion, Place and Space: A Framework for Investigating Historical Geographies of Religious Identities and Communities', Progress in Human Geography 30. 28-43. 
Butcher, Kevin 2011. 'Contesting Sacred Space in Lebanese Temples.' In Cultural Identity in the Ancient Mediterranean, ed. Erich S. Gruen. Los Angeles. 453-463.

Casey, Edward S. 1996. 'How to Get from Space to Place in a Fairly Short Stretch of Time.' In Senses of Place, ed. Steven Feld, Keith H. Basso. Santa Fe. 13-52.

Cifani, Gabriele; Stoddart, Simon 2012. Landscape, Ethnicity and Identity in the Archaic Mediterranean Area. Oxford.

Cumont, Franz 1912. s.v. Hadaranes, RE 7,2. 2163.

Dar, Shimon 1988. 'The History of the Hermon Settlements', Palestine Exploration Quarterly 120. 26-44.

Dar, Shimon; Kokkinos, Nikos 1992. 'Greek Inscriptions from Senaim on Mount Hermon', Palestine Exploration Quarterly 124. 9-25.

Freyberger, Klaus-Stefan 1999. 'Les temples de Niha. Témoins de cultes locaux d’influence romaine au Liban', Topoi 9. 569-577.

Gudme, Anne Katrine de Hemmer 2013. Before the God in this Place for Good Remembrance: A Comparative Analysis of the Aramaic Votive Inscriptions from Mount Gerizim. Berlin.

Guillon, Elodie 2013. Les arrière-pays des cités phéniciennes à l'époque héllénistique, IVe siècle - Ile siècle ap. J.-C.: approches historiques et spatiales d'une aire géoculturelle. $\mathrm{PhD}$ thesis. Toulouse.

Hajjar, Youssef 1990. 'Divinites oraculaires et rites divinitoires en Syrie et Phenice grécoromain', ANRW II.18.4, ed. Wolfgang Haase. Berlin. 2236-2320.

Hajjar, Youssef 1990a. 'Dieux et cultes non-héliopolitains de la Béqa', de l'Hermon et de l'Abilène à l'époque romaine', ANRW II.18.4, ed. Wolfgang Haase. Berlin. 2509-2604.

Hall, Johnathan M. 1998. 'Ethnic Identity in Greek Antiquity', Cambridge Archaeological Journal 98. 265-283. https://doi.org/10.1017/S0959774300001864.

Hermary, Antoine 2010. 'Inscriptions d'Amathonte IX. Un envoi de la mission Vogüé (1862) retrouvé au Louvre', Bulletin de correspondance hellénique 134.121-130.

Hodos, Tamar 2010. 'Local and Global Perspectives in the Study of Social and Cultural Identities.' In Material Culture and Social Identities in the Ancient World, ed. Shelley Hales, Tamar Hodos. Cambridge. 3-31.

Hošek, Anne-Rose 2012. Territoires et religions en contact: la colonie romaine de Berytus, de sa fondation au IIle siècle de notre ère. Histoire, École Pratique des Hautes Études de Paris. Unpublished thesis. https://hal.archives-ouvertes.fr/tel-01552363/document (accessed 30 October 2018).

Isaac, Benjamin 2009. 'Latin Cities in the Near East.' In From Hellenism to Islam. Cultural and Linguistic Change in the Roman Near East, ed. Helen M. Cotton et al. Cambridge. 43-72.

Kaizer, Ted 2005. 'Leucothea as Mater Matuta at Colonia Berytus: A Note on Local Mythology in the Levant and the Hellenisation of a Phoenician City', Syria 82.199-206.

Kaizer, Ted 2008. 'Introduction.' In The Variety of Local Religious Life in the Near East in Hellenistic and Roman Periods, ed. Ted Kaizer. Religions in the Graeco-Roman World 164. Leiden. 1-36.

Kaizer, Ted 2013. 'Creating Local Religious Identities in the Roman Near East.' In The Cambridge History of Religions in the Ancient World. Volume II, From the Hellenistic Age to Late Antiquity, ed. Michele R. Salzman, William A. Adler. Cambridge. 54-86.

Kaizer, Ted 2015. "“Familiar Strangers": Gods and Worshippers away from Home in the Roman Near East.' In Religious Identities in the Levant from Alexander to Muhammed, ed. Michael Blömer, Armin Lichtenberger, Rubina Raja. Continuity and Change 4. Turnhout. 19-32.

Kaizer, Ted 2016. 'Lucian on the Temple at Heliopolis', Classical Quarterly 66. 273-285. 
Kaizer, Ted (ed.) 2008. The Variety of Local Religious Life in the Near East in Hellenistic and Roman Periods. Religions in the Graeco-Roman World 164. Leiden/Boston.

Knott, Kim 2005. The Location of Religion: A Spatial Analysis. London.

Krencker, Daniel; Zschietzschmann, Willy 1938. Römische Tempel in Syrien nach Aufnahmen und Untersuchungen von Mitgliedern der deutschen Baalbekexpedition 1901-1904. Denkmäler antiker Architektur 5. Berlin.

Kropp, Andreas J. M. 2010. 'Jupiter, Venus and Mercury of Heliopolis (Baalbek): The Images of the "Triad" and Its Alleged Syncretisms', Syria 87. 229-264.

Kropp, Andreas. J. M. 2013. Images and Monuments of Near Eastern Dynasts, 100 BC-AD 100. Oxford.

Krumeich, R. 1998. 'Darstellungen syrischer Priester an den kaiserzeitlichen Tempeln von Niha and Chehim im Libanon', Damaszener Mitteilungen 10. 171-200.

Lefebvre, Henri 1974. La production de l'espace. Paris.

Lightfoot, Jane L. 2003. Lucian, On the Syrian Goddess, edited with Introduction, Translation and Commentary. Oxford.

Lott, John B. 2017. 'Women's Ritual Competence and A Self-Inscribing Prophet at Rome.' In Women's Ritual Competence in the Greco-Roman Mediterranean, ed. Matthew Dillon, Esther Eidinow, Lisa Maurizio. Abingdon. 199-212.

MacSweeney, Naoisé 2011. Community Identity and Archaeology: Dynamic Communities at Aphrodisias and Beycesultan. Ann Arbor.

Massey, Doreen 2004. 'Geographies of Responsibility', Geographiska Annaler. Series B Human Geopgraphy 86. 5-18.

Massey, Doreen 2005. For Space. London.

Millar, Fergus 1990. 'The Roman Coloniae of the Near East: A Study of Cultural Relations.' In Roman Eastern Policy and Other Studies in Roman History, ed. Heikki Solin, Mika Kajava. Helsinki. 7-58.

Millar, Fergus 1993. The Roman Near East, 31 B.C.-A.D. 337. Cambridge.

Mouterde, René 1934. 'Autel de Niha (Coelésyrie).' In Melanges Maspero. Vol 2: Orient Grec, Roman et Byzantin. Cairo. 69-70.

Newson, Paul; Young, Ruth 2015. 'The Archaeology of Conflict-Damaged Sites: Hosn Niha in the Biqa' Valley, Lebanon', Antiquity 89. 449-463.

Orsi, Robert 1997. 'Everyday Miracles: The Study of Lived Religion.' In Lived Religion in America: Toward a History of Practice, ed. David D. Hall. Princeton. 3-21.

Petridou, Georgia 2016. 'Aelius Aristides as Informed Patient and Physician.' In Homo Patiens: Approaches to the Patient in the Ancient World, ed. Georgia Petridou, Chiara Thumiger. Studies in Ancient Medicine 45. Leiden. 451-470.

Rey-Coquais, Jean-Paul 1981. 'Les frontières d'Hélioupolis. Quelques remarques.' In $L a$ géographie administrative et politique d'Alexandre à Mahomet. Actes du Colloque de Strasbourg 14-16 juin 1979. Leiden. 169-175.

Rey-Coquais, Jean-Paul 1987. 'Des montagnes au désert: Baetocécé, le pagus Augustus de Niha, la ghouta à l'est de Damas.' In Sociétés urbaines, sociétés rurales dans l'Asie Mineure et la Syrie hellénistiques et romaines, ed. Edmond Frézouls. Strasbourg. 191-216.

Rey-Coquais, Jean-Paul 1992. 'Sur quelques divinités de la Syrie antique.' In Mélanges Pierre Lévêque, vol. 6: Religion, ed. Marie-Madeleine Mactoux, Évelyne Geny. Besançon.

247-260. 
Ronzevalle, S. 1937. 'Jupiter héliopolitain, nova et vetera', Melanges de la Faculté Oriental de l'Université Saint-Joseph 21. 1-181.

Rüpke, Jörg 2011. 'Lived Ancient Religion', Mythos 5. 191-203.

Schuler, Christof 2012. 'Inscriptions and Identities of Rural Population Groups in Roman Asia Minor.' In Epigraphy and the Historical Science, ed. John Davies, John Wilkes. Oxford. 63-100.

Sartre, Maurice 1993. 'Du fait divers à l'histoire des mentalités: à propos de quelques noyés et de trois petis cochons', Syria 70. 51-67.

Sartre, Maurice 2001. The Middle East under Rome. Cambridge, MA.

Seyrig, Henri 1951. 'Antiquités syriennes', Syria 28. 101-123.

Seyrig, Henri 1954. 'Antiquités syriennes', Syria 31. 212-224.

Seyrig, Henri 1961. 'Nouveaux monuments de Baalbek et de la Beqaa', Bulletin du Musée de Beyrouth 16. 109-135.

Skupinska-Lovset, Ilona 1983. Funerary Portraiture of Roman Palestine. Upsala.

Sommer, Michael 2009. ,Imperiale Macht und lokale Identität: universalhistorische Variationen zu einem regionalhistorischen Thema.' In Lokale Identität im Römischen Nahen Osten, ed. Michael Blömer, Margherita Facella, Engelbert Winter. Stuttgart. 235-248.

Teixidor, Javier 1977. The Pagan God. Popular Religion in the Greco-Roman Near East. Princeton.

Versluys, Miguel J. 2015. 'Roman Visual Material Culture as Globalising Koine.' In Globalisation and the Roman World. World History, Connectivity and Material Culture, ed. Martin Pitts, Miguel J. Versluys. Cambridge. 141-174.

Yasmine, Jean 2009. 'Transformations monumentales de sanctuaires et de temples ruraux antiques. Les cas de Hardine et de Niha', Topoi 16. 121-152.

Yasmine, Jean 2013. 'The Niha Sites' (Lebanon) Cultural Landscape: A 3D Model of Sanctuaries and their Context', International Archives of Photogrammetry, Remote Sensings, and Spatial Information Science XL-5/W2. 699-704. 
